\title{
Influence of body position on exercise tolerance, heart rate, blood pressure, and respiration rate in coronary insufficiency ${ }^{1}$
}

\author{
Harry Lecerof \\ From the Department of Clinical Physiology, Malmö General Hospital, Malmö, Sweden
}

The influence of body position on exercise tolerance, heart rate, systolic blood pressure, and breathing frequency was studied during bicycle exercise in 37 male patients with coronary insufficiency. With identical work loads before the onset of angina pectoris, the heart rate was significantly higher in the supine position. Exercise tolerance was lower in the supine position, and angina pectoris developed at a significantly lower heart rate and systolic blood pressure.

The influence of body position on circulation has been studied extensively in normal subjects (Marshall and Shepherd, 1968) and in patients with heart disease (Abelmann and Fareeduddin, 1969; Epstein et al., 1969; Groden, 1969), but not during exercise in patients with angina pectoris. During exercise in the recumbent position there is an increased venous return to the heart and an increase in the heart volume (Holmgren and Ovenfors, 1960). In coronary insufficiency the increased venous return might be expected to aggravate the left ventricular impairment which characterizes this disorder (Müller and Rørvik, 1958; Malmborg, 1965), and therefore the pain threshold might be lower during supine exercise. This investigation was carried out to compare heart rate, systolic blood pressure, respiratory frequency, exercise tolerance, and pain threshold during exercise in the sitting and in the supine position.

\section{Subjects and methods}

Studies were carried out on 37 male patients aged 40-67 years. All had chest pain on exertion satisfying Rose's (I962) criteria for angina pectoris. Eight were out-patients and 29 were in-patients. Seven of the in-patients were exercised as part of a preoperative evaluation for coronary revascularization operations, and 22 underwent postoperative assessment; 14 of these had been treated by a diaphragmatic graft technique (Malm and Swedberg, 1963) and 8 by a modified Beck procedure (Beck and Leighninger, 1962). Thirty-two patients showed electrocardiographic evidence of Received 2 March 1970.

1 This work was supported by the Swedish Medical Research Council. coronary heart disease and only 5 had normal resting electrocardiograms. None had signs of congestive heart failure or valvular heart disease, and all were in sinus rhythm at the time of the study. Every patient was studied on two different days, usually with a time interval of 24 hours. Eighteen patients were exercised first in the sitting position (Group A), and 19 first in the supine position (Group B). The exercise tests were performed on the same electrically braked bicycleergometer. ${ }^{2}$ During exercise in the supine position, the pedal axis of the bicycle was approximately $20 \mathrm{~cm}$. above the table. The electrocardiogram was registered on a four- or six-channel direct writer $^{3}$ at a paper speed of $50 \mathrm{~mm}$./minute. Heart rates during exercise were calculated every minute from the electrocardiogram. The systolic blood pressure was measured every second minute, and just before the termination of the work by the auscultatory method with a sphygmomanometer cuff applied to the right arm. The breathing rate was measured by auscultation every second minute. The 'rate-pressure product' was calculated as the product of the systolic blood pressure and the heart rate and divided by 100 to reduce it to convenient units (Robinson, 1967). Ejection time correction was not performed as there were no intravascular pressure measurements.

The ST segment changes during exercise in 4 patients with normal electrocardiograms at rest were classified according to a modified Minnesota code (Astrand et al., 1967); the fifth patient with a normal electrocardiogram at rest showed no ST segment changes on exercise in either position.

\section{Results}

Average heart rates at identical work loads, sitting and supine (Table $I$ ) At the

\footnotetext{
2 Elema-Schönander, Stockholm, Sweden.

${ }^{3}$ Mingograph Elema-Schönander, 42 or 81 .
} 
TABLE I Average heart rates at identical work loads in sitting and supine positions

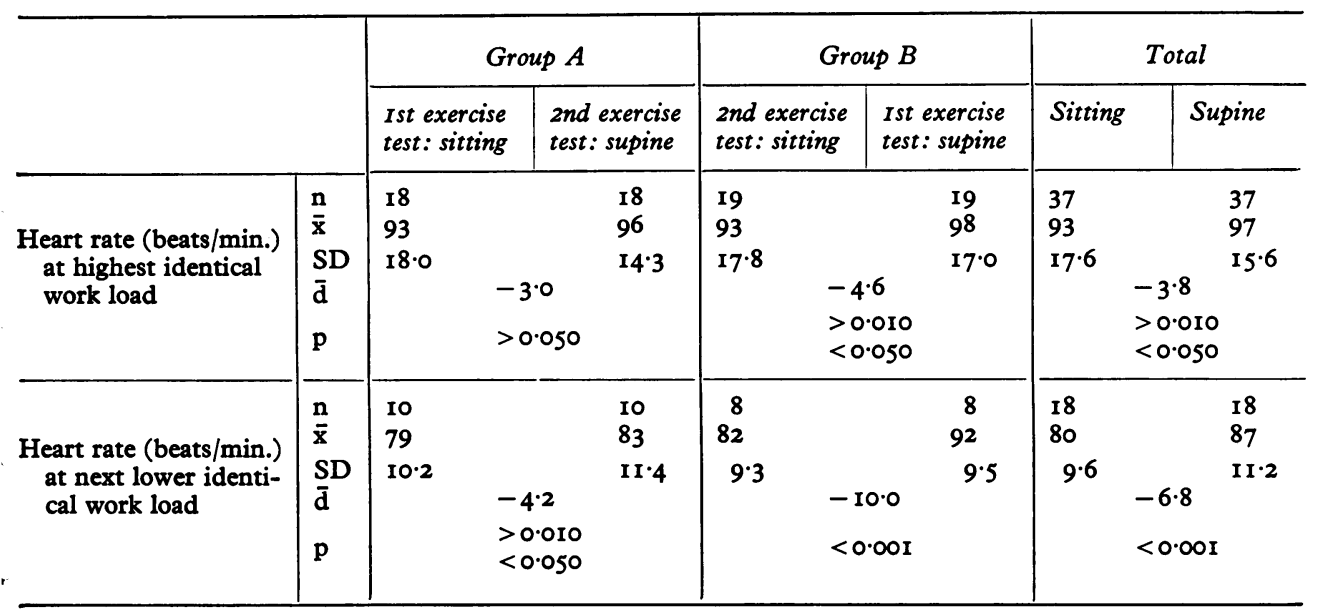

highest identical work load, the average sitting ' heart rate was 93 a minute compared with 97 a minute supine $(p<0.05)$. On the next lower work load, the average sitting heart rate was 80 - a minute compared with 87 a minute supine $(p<0.001)$. Thus, significantly higher heart rates were found in the supine position at identical work loads.

Systolic blood pressure and respiration rate at identical work loads (Table 2) No statistically significant differences were found

- TABLE 2 Systolic blood pressure and respiration rate at identical work loads, sitting and supine

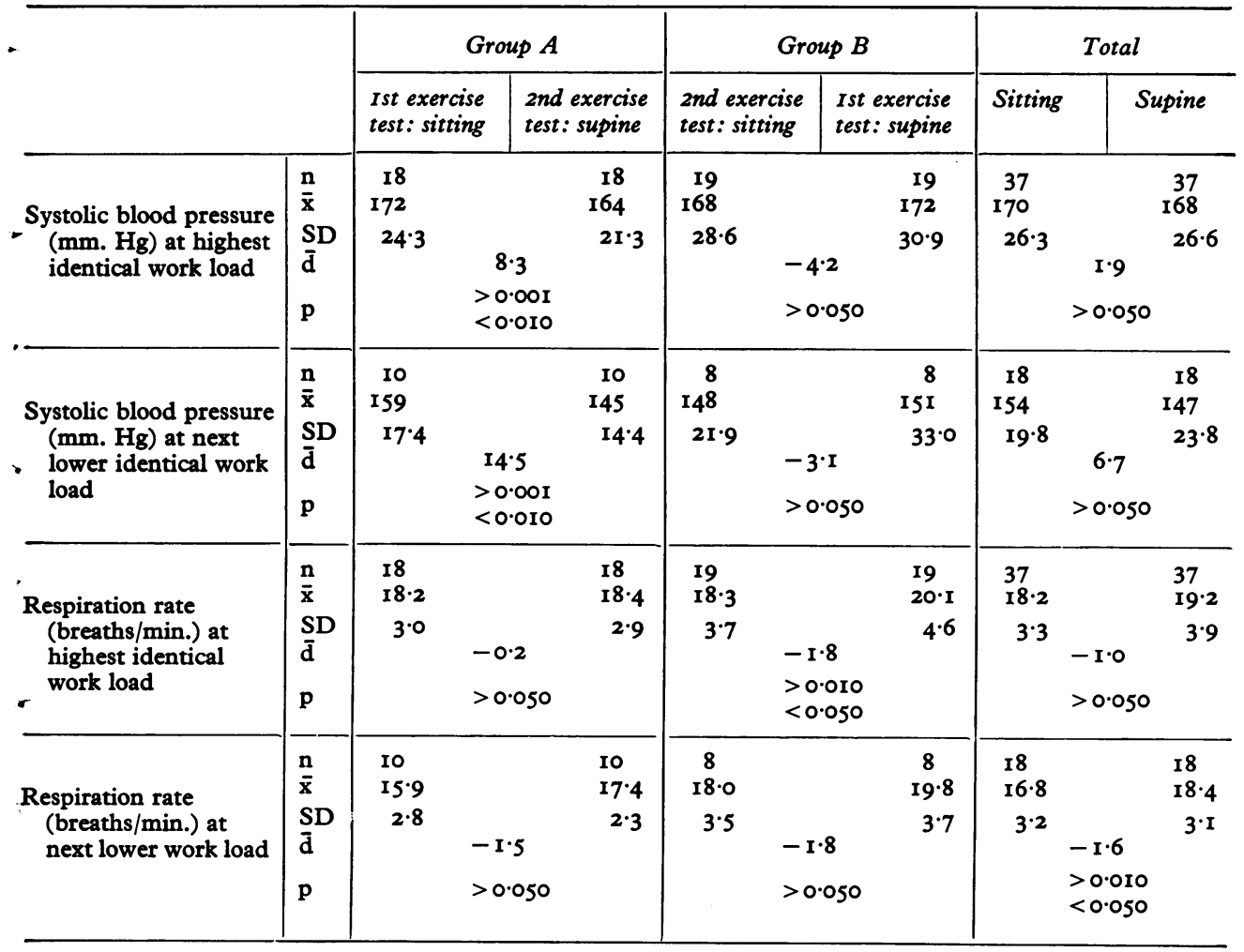


between values obtained in the sitting and supine positions. However, a tendency to a higher respiration rate was found in the supine position.

Work load, heart rate, systolic blood pressure, and rate-pressure product at termination of work (Table 3) Eight patients managed the same work load sitting and supine, while 29 were unable to achieve the same work load supine as when sitting. Nineteen patients only managed the first (lowest) work load in the supine position. The average work load sitting was $466 \mathrm{kpm}$./ minute compared with $324 \mathrm{kpm}$./minute supine, the difference being highly significant $(p<0.001)$. Exercise was terminated because of angina pectoris in 36 patients and claudication in one patient. At the termination of work, the mean value for the heart rates in the sitting position was II I a minute compared with IOI a minute supine, the difference being highly significant $(p<0 \cdot 001)$. The systolic blood pressure at the termination of work averaged $\mathrm{I} 88 \mathrm{~mm}$. $\mathrm{Hg}$ sitting compared with
I74 $\mathrm{mm}$. $\mathrm{Hg}$ supine, which difference is also highly significant $(p<0.001)$. Consequently the 'rate-pressure product' at the termination of work was significantly lower in the supine position ( $p<0.001)$. Angina pectoris thus developed at a lower heart rate and at a lower systolic blood pressure during supine work.

ST segment changes These changes in four patients with normal electrocardiograms at rest, at identical exercise levels sitting and supine, are given in Table 4. ST depression was, as a rule, greater in the supine position, pointing to more severe hypoxaemia of the myocardium in that position.

When the results in the surgically treated patients were analysed separately, the mean exercise tolerance sitting was $425 \mathrm{kpm}$./minute compared to $527 \mathrm{kpm}$./minute in the non-operated group $(p<0.05)$. In the supine position the average exercise tolerance for operated patients was $282 \mathrm{kpm}$./minute compared with $387 \mathrm{kpm}$./ minute for the non-operated group $(\mathrm{p}<0.05)$. There was no difference in exercise tolerance in the sitting or the supine position between patients

TABLE 3 Work load, heart rate, systolic blood pressure and rate-pressure product ${ }^{\star}$ at termination of work

\begin{tabular}{|c|c|c|c|c|c|c|c|}
\hline & & \multicolumn{2}{|c|}{ Group $A$} & \multicolumn{2}{|c|}{ Group B } & \multicolumn{2}{|c|}{ Total } \\
\hline & & $\begin{array}{l}\text { Ist exercise } \\
\text { test: sitting }\end{array}$ & $\begin{array}{l}\text { 2nd exercise } \\
\text { test: supine }\end{array}$ & $\begin{array}{l}\text { 2nd exercise } \\
\text { test: sitting }\end{array}$ & $\begin{array}{l}\text { Ist exercise } \\
\text { test: supine }\end{array}$ & Sitting & Supine \\
\hline $\begin{array}{l}\text { Work load (kpm./min.) } \\
\text { at termination of } \\
\text { work }\end{array}$ & $\begin{array}{l}\mathrm{n} \\
\overline{\mathbf{x}} \\
\mathrm{SD} \\
\overline{\mathrm{d}} \\
\mathrm{p}\end{array}$ & $\begin{array}{c}18 \\
497 \\
155 \cdot 7\end{array}$ & $\begin{array}{c}18 \\
336 \\
161 \cdot 6\end{array}$ & $\begin{array}{c}19 \\
437 \\
138 \cdot 3\end{array}$ & $\begin{array}{ll} & 19 \\
& 313 \\
& 149.9 \\
7 & \\
\infty & \end{array}$ & $\begin{array}{c}37 \\
466 \\
148 \cdot 2\end{array}$ & $\begin{array}{ll} & 37 \\
& 324 \\
& 153.9 \\
9 & \end{array}$ \\
\hline $\begin{array}{l}\text { Heart rate (beats/min.) } \\
\text { at termination of } \\
\text { work }\end{array}$ & $\begin{array}{l}n \\
\bar{x} \\
S D \\
\bar{d} \\
p\end{array}$ & \multicolumn{2}{|c|}{$\begin{array}{l}12.6 \\
<0.001\end{array}$} & $\begin{array}{r}19 \\
112 \\
15.9\end{array}$ & $\begin{array}{c}19 \\
104 \\
16.0\end{array}$ & $\begin{array}{l}37 \\
\text { III } \\
17 \cdot 6\end{array}$ & $\begin{array}{cc} & 37 \\
& 101 \\
& 16 \cdot 0 \\
9 & \end{array}$ \\
\hline $\begin{array}{l}\text { Systolic blood pressure } \\
\text { (mm. Hg) at termin- } \\
\text { ation of work }\end{array}$ & $\begin{array}{l}\mathrm{n} \\
\overline{\mathbf{x}} \\
\mathrm{SD} \\
\overline{\mathrm{d}} \\
\mathrm{p}\end{array}$ & \multicolumn{2}{|c|}{$\begin{array}{l}20.3 \\
<0.001\end{array}$} & \multicolumn{2}{|c|}{$\begin{aligned} & 9.2 \\
> & 0.001 \\
< & 0.010\end{aligned}$} & $\begin{array}{r}35 \\
188 \\
32 \cdot 2\end{array}$ & $\begin{array}{cc} & 35 \\
& 174 \\
& 28 \cdot 4 \\
4 & \\
& \end{array}$ \\
\hline $\begin{array}{l}\text { Rate-pressure product } \\
\text { at termination of } \\
\text { work }\end{array}$ & $\begin{array}{l}n \\
\bar{x} \\
S D \\
\bar{d} \\
p\end{array}$ & $\begin{array}{r}17 \\
213 \\
57\end{array}$ & $\begin{array}{r}17 \\
168 \\
39\end{array}$ & $\begin{array}{r}18 \\
210 \\
49\end{array}$ & $\begin{array}{r}18 \\
187 \\
48\end{array}$ & $\begin{array}{r}35 \\
211 \\
53\end{array}$ & $\begin{array}{r}35 \\
178 \\
44 \\
\\
\end{array}$ \\
\hline
\end{tabular}

$\star$ Rate-pressure product $=\frac{\text { systolic blood pressure }(\mathrm{mm} . \mathrm{Hg}) \times \text { heart rate (beats } / \mathrm{min} .)}{100}$ 
-

TABLE $4 S T$ depression in CR leads sitting and supine (Minnesota code as modified by Astrand et al., 1967)

\begin{tabular}{|c|c|c|c|c|c|c|c|c|}
\hline & \multicolumn{2}{|c|}{ Patient I } & \multicolumn{2}{|c|}{ Patient 2} & \multicolumn{2}{|c|}{ Patient 3} & \multicolumn{2}{|c|}{ Patient 4} \\
\hline & Sitting & Supine & Sitting & Supine & Sitting & Supine & Sitting & Supine \\
\hline $\begin{array}{l}\text { - Highest work load } \\
\text { Immediately after exercise } \\
5 \text { minutes after exercise }\end{array}$ & $\begin{array}{l}3 \\
3 \\
3\end{array}$ & $\begin{array}{l}\text { I } \\
\text { I } \\
\text { None }\end{array}$ & $\begin{array}{l}2 \\
3 \\
7\end{array}$ & $\begin{array}{l}\text { I } \\
\text { None }\end{array}$ & $\begin{array}{l}\text { None } \\
\text { None } \\
\text { None }\end{array}$ & $\begin{array}{l}5 \\
5 \\
\text { None }\end{array}$ & $\begin{array}{l}4 \\
5 \\
5\end{array}$ & $\begin{array}{l}1 \\
3 \\
5\end{array}$ \\
\hline
\end{tabular}

Note: The most severe ST depression is represented by code number $\mathrm{I}$ and the least severe by code number 7 .

who had a Beck operation and patients operated upon by the diaphragmatic graft technique. The tendency to higher heart rates at equal work loads when supine was present in the 'Beck group' as swell as in the 'diaphragmatic graft group'.

\section{Discussion}

-In young healthy men no difference in heart rate was observed at the same work load performed on a bicycle in the sitting and in the supine position (Bevegård, Holmgren, and 'Jonsson, 1960, 1963; Hellström and Holmgren, 1966). In young women, a tendency to higher heart rates in the sitting position has been reported, but the difference was not statistically significant (Hellström and Holmgren, 1966). McGregor, Adam, and Sekelj (I96I) found, in normal subjects, a higher heart rate and a higher respiratory frequency during bicycle work in the sitting compared with the supine position, but they studied only four subjects. The circulation in healthy old men was studied by right heart catheterization during exercise in the sitting and supine position by Granath, Jonsson, and Strandell I964). No difference in heart rate was found jetween equal work loads performed sitting ind supine. The stroke volume and the carliac output were lower at identical work loads serformed sitting. The systolic and diastolic Irterial blood pressures were slightly higher n the sitting position, but the differences were lot statistically significant (Granath, 1965; Jranath et al., 1964). The influence of body osition on heart volume during exercise was tudied by Holmgren and Ovenfors (I960). They found, on the average, a lower heart olume during exercise in the sitting position Smpared with that in the supine position. Thus, it seems that in normal subjects, at the ame work load, there is no difference in heart tte and blood pressure, whereas heart volme, stroke volume, and cardiac output Icrease in the supine position.

In patients with heart failure, Epstein et al. 969) found significantly higher heart rates 6 in the supine position when comparing supine and sitting bicycle exercise. However, the implications of this finding on the mechanism of contraction of the heart were not discussed. Haemodynamically, the patient with coronary insufficiency is characterized by impairment of left ventricular function at least during exercise (Müller and Rørvik, I958; Malmborg, 1965), which means a flattened relation between end-diastolic volume and stroke volume in the Frank-Starling diagram and a diminished ability to shift the ventricular function curve upwards and to the left during exercise (Ross, 1966). In spite of greatly increased end-diastolic volume and end-diastolic pressure, the patient with coronary insufficiency has a very limited ability to increase his stroke volume (Braunwald, Ross, and Sonnenblick, 1967). According to the law of Laplace, the increment in end-diastolic volume means that an increased load is imposed upon the heart (Burton, 1957). As a consequence of the raised end-diastolic pressure in the left ventricle, the pressure gradient between the coronary arteries and the small intramural vessels of the ventricular wall is reduced with a consequent decrease in coronary blood flow. Thus, on theoretical grounds, work in the supine position in patients with coronary insufficiency ought to lower the myocardial blood flow and this constitutes the logical explanation for the lower exercise tolerance observed in the supine position.

The higher heart rates observed during supine exercise before the development of chest pain (Table I) suggest that, in order to keep myocardial oxygen consumption low, these hearts deliver a smaller stroke volume at a faster heart rate. This indicates that in coronary heart disease the disadvantage of a shorter diastole is less than that of an increased stroke volume, requiring an increased ventricular wall tension.

There is some controversy about whether the increment in left ventricular end-diastolic pressure observed during exercise in patients with coronary insufficiency is due to decreased 
left ventricular compliance or to left ventricular failure (Glancy et al., 1969; Parker et al., 1969; Wiener, Dwyer, and Cox, 1968). The higher heart rates observed here in the supine position at identical work loads are consistent with decreased left ventricular compliance, which however does not rule out impairment of left ventricular function (Linhart et al., 1969). If decreased compliance of the left ventricular wall is presumed, a higher heart rate would be advantageous, since it means that the ventricle could expel the same cardiac output with a smaller stroke volume at a lower energy expenditure. As evident from Table 3, these patients experience chest pain at a lower heart rate and give up work at a lower work load during supine exercise. This is a consequence of left ventricular dysfunction with increased end-diastolic volume and pressure, changes that characterize coronary insufficiency at the onset of angina pectoris (Müller and Rørvik, 1958; Malmborg, I965; Parker, Di Giorgi, and West, 1966). The order of magnitude of the mean difference in exercise tolerance could have practical implications when an endurable exercise level for a heart catheterization study has to be determined from a work test in the sitting position.

The explanation for the tendency to a higher respiration rate observed during supine work may be that the pulmonary blood volume is increased in that position. In patients with left ventricular impairment, the difference in pulmonary blood volume between the supine and the sitting position is further accentuated as the heart cannot handle the increased inflow properly (Wang, Marshall, and Shepherd, 1960).

Robinson has employed the product of the heart rate and systolic blood pressure as a rough index of myocardial oxygen requirements and has shown that the onset of angina pectoris occurs at a rate-pressure product that is remarkably constant for each patient (Robinson, 1967). The differences in ratepressure products observed here, between sitting and supine exercise, simply show that this index is not valid for predicting anginal pain when changes in heart size and duration of ejection time are not taken into account as stated originally by Robinson. Such changes could be brought about by changing the body position or by means of pharmacological agents, e.g. nitroglycerin and beta-receptor blocking agents (Epstein and Braunwald, 1968). The significantly lower rate-pressure products encountered during supine work may be taken as indirect evidence of increased ventricular size.

\section{References}

Abelmann, W. H., and Fareeduddin, K. (1969). Increased tolerance of orthostatic stress in patients with heart disease. American fournal of Cardiology, 23, 354 .

Asstrand, I. et al. (1967). The 'Minnesota code' for ECG classification. Adaptation to $C R$ leads and modification of the code for ECGs recorded during and after exercise. Acta Medica Scandinavica, Suppl. 481 .

Beck, C. S., and Leighninger, D. S. (1962). Coronary heart disease treated by operation. Archives of Surgery, 85, 383.

Bevegård, S., Holmgren, A., and Jonsson, B. (1960). The effect of body position on the circulation at rest and during exercise, with special reference to the influence on the stroke volume. Acta Physiologica Scandinavica, 49, 279.

,-- , and - (1963). Circulatory studies in well trained athletes at rest and during heavy exercise, with special reference to stroke volume and the influence of body position. Acta Physiologica Scandinavica, 57, 26.

Braunwald, E., Ross, J., and Sonnenblick, E. H. (1967). Mechanisms of contraction of the normal and failing heart. New England fournal of Medicine, 277, IOI2.

Burton, A. C. (1957). Editorial. The importance of the shape and size of the heart. American Heart fournal, 54, 801 .

Epstein, S. E., Beiser, G. D., Stampfer, M., and Braunwald, E. (1969). Exercise in patients with heart disease. Effects of body position and type and intensity of exercise. American fournal of Cardiology, 23, 572.

adrenergic nervous system in the treatment of angina pectoris. Medical Clinics of North America, 52, 1031 .

Glancy, D. L., Higgs, L. M., O'Brien, K. P., and Epstein, S. E. (1969). The effect of digitalis on left ventricular response to exercise in patients with angina. Circulation, 40, Suppl. 3, p. 89.

Granath, A. (1965). Mitral valvulotomy. A clinical and hemodynamic pre- and postoperative study. Acta Medica Scandinavica, 178, Suppl. 433.

—, Jonsson, B., and Strandell, T. (1964). Circulation in healthy old men, studied by right heart catheterization at rest and during exercise in supine and sitting position. Acta Medica Scandinavica, 176, 425.

Groden, B. M. (1969). Effect of posture on cardiac output after myocardial infarction. British Heart Fournal, 31, 735 .

Hellström, R., and Holmgren, A. (1966). On the repeatability of submaximal work tests and the influence of body position on heart rate during exercise at submaximal work loads. Scandinavian Fournal of Clinical and Laboratory Investigation, 18, 479.

Holmgren, A., and Ovenfors, C. O. (1960). Heart volume at rest and during muscular work in the supine and in the sitting position. Acta Medica Scandinavica, 167, 267.

Linhart, J. W., Hildner, F. J., Barold, S. S., Lister, J. W., and Samet, P. (1969). Left heart hemodynamics during angina pectoris induced by atrial pacing. Circulation, 40, 483.

McGregor, M., Adam, W., and Sekelj, P. (I96r). Influence of posture on cardiac output and minute ventilation during exercise. Circulation Research, 9, 1089. 
Malm, A., and Swedberg, J. (1963). Considerations on surgery of coronary diseases. In Studies in Surgery, dedicated to Helge B. Wulff, Malmö, I963, p. 169. Malmö.

Malmborg, R. O. (1965). A clinical and hemodynamic analysis of factors limiting the cardiac performance in patients with coronary heart disease. Acta Medica Scandinavica, 177, Suppl. 426.

- Marshall, R. J., and Shepherd, J. T. (1968). Cardiac Function in Health and Disease. Saunders, Philadelphia.

Müller, O., and Rørvik, K. (1958). Hemodynamic

- consequences of coronary heart disease; with observations during anginal pain and on the effect of nitroglycerin. British Heart fournal, 20, 302.

Parker, J. O., Di Giorgi, S., and West, R. O. (1966). A hemodynamic study of acute coronary insuffici-

- ency precipitated by exercise, with observations on the effects of nitroglycerin. American fournal of Cardiology, 17, 470.

-, West, R. O., Ledwich, J. R., and Di Giorgi, S.

- (1969). The effect of acute digitalization on the hemodynamic response to exercise in coronary artery disease. Circulation, 40, 453.

Robinson, B. F. (1967). Relation of heart rate and systolic blood pressure to the onset of pain in angina pectoris. Circulation, 35, 1073.

Rose, G. A. (I962). The diagnosis of ischaemic heart pain and intermittent claudication in field surveys. Bulletin of the World Health Organization, 27, 645.

Ross, J. in Braunwald, E. et al. (1966). Congestive heart failure. Biochemical and physiological considerations. (Combined Clinical Staff Conference at the National Institutes of Health.) Annals of Internal Medicine, 64, 904.

Wang, Y., Marshall, R. J., and Shepherd, J. T. (1960). The effects of changes in posture and of graded exercise on stroke volume in man. Fournal of Clinical Investigation, 39, 105I.

Wiener, L., Dwyer, E. M., and Cox, J. W. (1968). Left ventricular hemodynamics in exercise-induced angina pectoris. Circulation, 38, 240. 